\title{
Pengaruh Penyesuaian Diri terhadap Kepuasan Pernikahan pada Individu yang Menikah melalui Proses Ta'aruf
}

\author{
Muhammad Abbas ${ }^{1}$ \\ Fakultas Psikologi, Universitas Muhammadiyah Malang \\ e-mail: ${ }^{1}$ abbasdenta511@gmail.com
}

\begin{abstract}
Satisfaction in a marriage is very important because it is a part of appraisement and evaluation, whether the marriage can to proceed or have many conflict. adjusements of a person will be the basis for the achievement of marital satisfaction, this also happens to a person who marriage trough by ta'aruf process. The research aims to investigate the influence of self-adjusment on marital satisfaction to person marriage trough by ta'aruf process. The type of research is by quantitative with 118 subjects who marriage trough by ta'aruf process. The subjects were taking by snowball sampling technique. From the retrival of data that result of the coeffition of determination or $r 2=$ 0,268 with a significant value is 0,000 so that the selfadjustment on marital satisfaction to person who marriage trough by ta'aruf process gives a small influence with a value $26,8 \%$.
\end{abstract}

KEYWORDS marriage, self-adjustment, marital satisfaction, ta'aruf

CITATION Abbas, M. (2019). Pengaruh penyesuaian diri terhadap kepuasan pernikahan pada individu yang menikah melalui proses ta'aruf. Cognicia, 7 (1), 112-120.

Manusia adalah makhluk sosial yang selalu membutuhkan orang lain dalam memenuhi kebutuhan hidupnya. Hubungan yang terjalin dapat berupa hubungan pertemanan, persahabatan dan pernikahan. Pada saat seseorang memasuki masa dewasa awal, maka tugas dan kewajiban seseorang akan bertambah seperti tugas untuk mencari pekerjaan, melanjutkan pendidikan, dan membentuk keluarga. Pada periode ini seseorang akan berada pada tahap dimana seseorang membangun hubungan yang dekat dan siap berkomitmen dengan orang lain serta mengembangkan hubungan yang intim. Tugas perkembangan pada masa dewasa awal yang sangat penting salah satunya adalah pernikahan.

Kepuasan dalam pernikahan merupakan hal yang sangat penting dirasakan oleh individu yang melakukan pernikahan, karena merupakan bagian dari sebuah penilaian apakah pernikahan yang dijalankan berjalan sesuai dengan harapan ataukah tidak sesuai. Pada pasangan yang menikah muda misalnya, sebagaimana yang dikatakan oleh Lee (Ayuningtyas, 2015) pasangan yang menikah muda sangat memungkinkan untuk merasakan kekurangan pada hubungan pernikahan sehingga menimbulkan ketidakpuasan dalam pernikahan. Pernikahan tersebut bisa saja menjadi langgeng selamanya atau bercerai ditengah jalan karena dipicu oleh faktorfaktor yang mempengaruhi kepuasan pernikahan. 
Undang-Undang Pernikahan No. 1 tahun 1974, menjelaskan bahwa pernikahan sebagai "Ikatan lahir batin antara seorang pria dan wanita sebagai suami dan istri dengan tujuan membentuk keluarga (rumah tangga) yang bahagia dan kekal berdasarkan Ketuhanan Yang Maha Esa". Pernikahan tidak hanya bersatunya pria dan wanita secara lahir namun juga secara batin. Sehingga pernikahan bukan hanya sekedar pemenuhan hasrat biologis semata akan tetapi lebih mengarah pada proses penyatuan dua keluarga yang berbeda terlebih lagi pada proses peribadatan kepada Allah dengan membangun keluarga atau rumah tangga.

Mencari pasangan hidup atau melakukan proses pernikahan, masyarakat biasanya menggunakan berbagai macam cara seperti melakukan penjajakan dengan cara berpacaran. Mereka beralasan bahwa dengan berpacaran mereka dapat lebih memahami sifat dan karakter calon pasangan secara lebih mendalam sehingga tidak ada keraguan lagi untuk menuju pernikahan. Sedangkan dalam ajaran agama Islam, untuk mencari pasangan dikenal dengan istilah ta'aruf yang berasal dari akar kata bahasa arab yang berarti "saling kenal-mengenal". Hidayat (Elhakim, 2015) mengatakan bahwa pengertian ta'aruf adalah komunikasi antara laki-laki dan perempuan untuk saling saling memperkenalkan diri yang berkaitan dengan masalah pernikahaan. Alasan orang memilih ta'aruf adalah karena ta'aruf lebih bisa menjaga diri dari hal-hal yang tidak di inginkan seperti terjadinya perzinahan dan lain-lain. Sebagaimana disebutkan dalam sebuah Hadits bahwasanya Rasulullah SAW. Bersabda: "Janganlah seorang laki-laki bertemu sendirian (bersepi-sepi) dengan perempuan yang tidak halal baginya, karena yang ketiganya adalah setan". (H.R. Imam Ahmad dari Amir bin Robi'ah ra). Hadits ini menjelaskan tentang larangan untuk berduaduaan bagi pasangan yang belum menikah atau belum sah sebagai suami istri karena merupakan salah satu pintu keburukan, dan juga pasangan yang melakukan proses ta'aruf beralasan jika sesuatu dilakukan dimulai dengan hal-hal yang baik, maka akan menghasilkan sesuatu yang baik pula. Begitupun dengan pernikahan harus dimulai dengan proses yang baik sehingga akan menghasilkan pernikahan dan keturunan yang baik.

Konflik-konflik dalam keluarga akan menyebabkan ketidakpuasan dalam pernikahan yang suatu saat akan menyebabkan perceraian. Kepuasan pernikahan merupakan hasil evaluasi terhadap hubungan pernikahan yang dilalui oleh pasangan suami istri. Kepuasan pernikahan menjadi faktor penting dalam keberhasilan kehidupan pernikahan, jika salah satu dari pasangan tersebut tidak merasakan kepuasan dikarenakan harapan yang tidak sesuai keinginan, maka akan menimbulkan kekecewaan yang lama-kelamaan akan menimbulkan konflik dalam keluarga yang beresiko pada perceraian. Sebagaimana yang dikatakan Adhim (Elhakim, 2015) persepsi terhadap pasangan akan menumbuhkan harapan-harapan tertentu terhadap pernikahan. Jika harapan-harapan tersebut tidak terpenuhi maka akan berpengaruh pada kepuasan pernikahan.

Keberhasilan dalam mencapai kepuasan pernikahan sangat dipengaruhi oleh penyesuaian diri terhadap pasangan, sebagaimana yang dikatakan oleh Hurlock (2003) menjelaskan bahwa setiap individu yang berada pada masa awal pernikahan dituntut untuk menyatukan banyak hal dalam diri masing-masing. Individu yang mampu menyatukan aspekaspek tersebut, dapat berpengaruh pada harmonisasi dalam rumah 
tangga mereka. Penyatuan perbedaan dari masing-masing individu terhadap pasangannya, sangat dipengaruhi oleh kematangan masing-masing dalam melakukan penyasuaian diri. Sehingga dari penyesuaian diri yang baik dari masing-masing individu, mereka dapat membina rumah tangga yang baik yang dimana akan berdampak pada masa-masa pernikahan mereka selanjutnya.

Pada saat seorang pria dan wanita akan menikah tentunya masingmasing membawa nilai budaya, sikap, keyakinan dan gaya penyesuaiannya yang berbeda ke dalam rumah tangga yang akan mereka bangun. Penyatuan-penyatuan harapan dalam pernikahan tidaklah mudah, perlu perencanaan yang matang dan penyesuaian diri yang baik dan penerimaan terhadap pasangan. Penyesuaian diri yang matang akan mempermudah dalam proses penyatuan prinsip bahkan persepsi yang di miliki oleh suami dan istri karena harus membangun persepsi yang baru agar harapan-harapan terhadap ekspektasi dalam pernikahan bisa terwujud.

Tahun-tahun pertama perkawinan merupakan masa rawan, bahkan dapat disebut sebagai era kritis karena pengalaman bersama belum banyak sebagaimana yang dikatakan oleh Anjani, C \& Suryanto (2006). Sedangkan menurut Clinebell \& Clinebell (Anjani, C \& Suryanto, 2006) masa awal pernikahan merupakan masa-masa penyesuaian diri, dimana banyaknya muncul krisis-krisis dalam sebuah pernikahan., sehingga masing-masing individu dituntut untuk harus banyak belajar terkait masalah yang dihadapi serta kepribadian masing-masing sehingga pasangan tersebut dapa saling menempa, memberi, dam menerima satu sama lain. Duvall, E, M \& Miller, B (1985) mengatakan bahwa masa awal pernikahan antara 1-5 tahun merupakan masa krisis yang menentukan keberhasilan pernikahan. Pada masa ini pasangan suami istri menghadapi dan menjalani semua tuntutan dalam berumah tangga. Penyesuaian diri yang dilakukan bukan hanya antar suami dan istri akan tetapi penyesuaian diripun dilakukan kepada keluarga besar masing-masing individu sehingga pasangan suami istri tersebut akan merasakan dukungan yang baik dari keluarga besar masing-masing.

Periode awal pernikahan merupakan hal baru bagi individu dimana mereka masing-masing memiliki harapan dan keinginan terhadap pasangan dalam menjalani rumah tangga. Permasalahan yang terjadi di awal pernikahan akan tetap berlangsung bahkan sampai terjadi perceraian dikarenakan pasangan tersebut tidak mampu untuk melakukan penyesuaian diri terhadap pasangannya. Pasangan tersebut belum mampu menerima perbedaan-perbedan yang ada pada diri masing-masing sehingga terjadilah konflik dalam pernikahannya.

Bowman (Dewi, 2009) penyesuaian diri dalam pernikahan bersifat dinamis, pasangan suami istri saling menyesuaikan diri satu sama lain hingga mencapai hubungan yang harmonis dan memuaskan. Kegagalan dalam menyesuaikan diri akan berdampak pada kondisi psikologis dari pasangan tersebut seperti stress dan depresi karena menghadapi situasi yang penuh tekanan.

Al-Jauziyah, (2016) mengatakan bahwa cinta sejati lahir dari kecocokan tujuan kita dengan tujuan orang yang dicintai. Dalam hal ini, kita bisa mengambil kesimpulan bahwa jika ingin mencapai cinta sejati maupun kepuasan dalam pernikahan, maka suami harus menyatukan tujuan atau harapan yang dia miliki dengan tujuan dan harapan yang dimiliki oleh istri. Karena persoalan tingkah laku dan harapan terhadap pasangan yang tidak sesuai dapat menimbulkan kekecewaan, begitupun sebaliknya 
jika tingkah laku dan harapan terhadap pasangan sesuai dengan yang di inginkan maka akan menimbulkan perasaan senang dan bahagia. Penyatuan tujuan dan harapan ini tidak bisa terjadi jika pasangan tersebut tidak mampu menerima dan menyesuaikan diri terhadap perbedaan-perbedaan persepsi masing-masing.

Kemudian dari fenomena ta'aruf yang saat ini terjadi sebagaimana yang dikatakan oleh Elhakim (2015) proses pencarian pasangan dengan melalui proses ta'aruf semakin berkembang, dikarenakan masyarakat saat ini merasa bahwa proses ta'aruf merupakan proses yang paling aman karena dapat menghindarkan dari perzinahan sehingga perilaku-perilaku amoral dapat terhindarkan, kemudian adanya keyakinan bahwa Allah akan mempersiapkan jodoh sesuai keadaan diri seseorang, kemudian yang terpenting adalah adanya faktor agama yang dimana menunjukkan tingkatan pemahaman dari individu yang melangsungkan ta'aruf tentang ajaran dan syari'at dalam agama. Maka dari itu, penelitian ini berfokus pada individu yang menikah dengan proses ta'aruf dikarenakan melihat individu tersebut menikah dengan proses penjajakan yang relatif singkat sehingga rentan terhadap permasalahan pada penerimaan individu dengan individu yang lainnya.

Tujuan dari penelitian ini adalah untuk mengetahui pengaruh penyesuaian diri terhadap kepuasan pernikahan pada individu yang menikah melalui proses ta'aruf. Kemudian manfaat dari penelitian ini adalah dapat memberi informasi terhadap pengembangan Ilmu Psikologi dalam lingkup Keluarga serta mampu menjadi tambahan informasi pada penelitian-penelitian selanjutnya. Penelitian ini juga diharapkan dapat memberikan edukasi kepada masyarakat terhadap konsep pernikahan melalui proses ta'aruf yang secara agama lebih menjaga diri dari hal-hal yang tidak baik bagi pasangan yang akan menikah. Serta memberikan informasi tambahan bagi pasangan yang sedang melakukan proses ta'aruf.

\section{METODE}

Penelitian ini, penulis melakukan penelitian kuantitatif dimana proses penggalian informasi diwujudkan dalam bentuk angka-angka sebagai alat untuk menemukan keterangan mengenai apa yang diketahui. Penulis menggunakan jenis penelitian yang bersifat kuantitatif, sebab dalam penelitian ini peneliti ingin menggali lebih jauh bagaimana pengaruh suatu variabel tertentu dapat mempengaruhi variabel tertentu yang lain berdasarkan angka atau nilai pada suatu item yang diajukan, yaitu pengaruh penyesuaian diri terhadap kepuasan pernikahan pada individu yang menikah melalui proses ta'aruf. Maka untuk mengetahui pengaruh tersebut, maka digunakan beberapa rumus statistik, sehingga penelitian ini dikenal dengan penelitian kuantitatif.

Pengambilan sampel subjek dalam penelitian ini menggunakan nonprobability sampling yaitu teknik pengambilan sampel yang tidak memberi peluang atau kesempatan yang sama bagi setiap unsur atau anggota populasi untuk dipilih menjadi sampel, Sugiyono (2011). Pada teknik ini berfokus pada Snowball Sampling, yaitu teknik penentuan sampel yang mula-mula jumlahnya kecil, kemudian membesar, Sugiyono (2011). Dalam penelitian ini terdapat 118 subjek, subjek penelitian ini adalah individu atau suami dan istri yang sudah menikah dalam interval waktu 1-5 tahun, kemudian 
pernikahan subjek yaitu tanpa pacaran, mendapatkan pasangan dari saran teman atau orang terdekat, dengan saling mengajukan $\mathrm{CV}$.

Tabel 1. Deskripsi Data Subjek

\begin{tabular}{ccc}
\hline Kategori & Jumlah & Persentase \\
\hline Jenis kelamin & & \\
Laki-laki & 13 & $11 \%$ \\
Perempuan & 105 & $89 \%$ \\
\hline Lama menikah & & \\
1 tahun & 29 & $25 \%$ \\
2 tahun & 35 & $30 \%$ \\
3 tahun & 23 & $19 \%$ \\
4 tahun & 18 & $15 \%$ \\
5 tahun & 13 & $11 \%$ \\
\hline Usia Saat Menikah & & \\
19-21 tahun & 58 & $40 \%$ \\
22-40 tahun & 60 & $60 \%$ \\
\hline Total & $\mathbf{1 1 8}$ & \\
\hline
\end{tabular}

Pada penelitian ini terdapat dua variabel yaitu variabel bebas $(X)$ dan variabel terikat $(\mathrm{Y})$. Adapun yang menjadi variabel bebasnya adalah penyesuaian diri dan yang menjadi variabel terikatnya adalah kepuasan pernikahan.

Kepuasan pernikahan merupakan hasil evaluasi suami atau istri yang menjalankan ta'aruf terkait keadaan pernikahan yang individu tersebut jalankan.. Dalam pengukuran kepuasan pernikahan ini, peneliti mengadaptasi teori yang dikembangkan oleh Fower dan Olson yaitu dari skala ENRICH Marital Satisfaction Scale (EMS) yang berjumlah 10 item yang selanjutnya alat ukur tersebut dikembangkan kembali oleh peneliti menjadi 60 item yang mewakili dari 10 aspek yang ditentukan. Aspek-aspek yang akan diukur pada kepuasan pernikahan ini ialah: (1). Communication. (2). Leisure activity. (3). Religious orientation. (4). Conflict resolution. (5). Financial management. (6). Sexual orientation. (7). Family and friends. (8). Personality issue. (9). Egalitarian role. (10). Parenting.

Kemudian penyesuaian diri merupakan proses adaptasi individu pada sebuah lingkungan, serta bagaimana individu menampilkan perannya pada lingkungan tersebut. Pada pengukuran penyesuaian diri ini, peneliti menggunakan skala buatan sendiri yang mengacu pada teori yang dikembangkan oleh Schneiders, kemudian dikembangkan oleh peneliti menjadi 28 item yang mewakili 7 aspek yang telah ditentukan. Aspek yang akan di ukur dalam penyesuaian diri ini ialah: (1) Tidak memiliki emosi yang berlebihan. (2) Tidak memiliki perasaan frustasi pribadi. (3) Tidak memiliki mekanisme psikologis. (4) Memiliki pertimbangan rasional dan kemampuan mengarahkan diri. (5) Memiliki kemampuan untuk belajar. (6) Memiliki kemampuan menggunakan pengalaman masa lalu. (7) Memiliki sikap realistik dan objektif. 
Kedua alat ukur dalam penelitian ini menggunakan skala likert yang disusun dengan item yang mendukung konsep (favorable) dan item yang tidak mendukung konsep (unfavorable). Pada setiap item pada kelompok pernyataan tersebut mempunyai empat pilihan jawaban yaitu: Sangat Sesuai (SS), Sesuai (S), Tidak Sesuai (TS), dan Sangat Tidak Sesuai (STS). Secara jelas dirincikan sebagai berikut: sangat sesuai (SS) pada favorable diberikan nilai 4 dan unfavorable nilai 1, sesuai (S) pada favorable diberikan nilai 3 dan unfavorable nilai 2, tidak sesuai (TS) pada favorable diberikan nilai 2 dan unfavorable nilai 3, dan sangat tidak setuju (STS) pada favorable diberikan nilai 1 dan unfavorable nilai 4.

Secara umum penelitian ini memiliki beberapa tahapan sebagai berikut:

Tahap persiapan dilakukan pendalaman materi yang terkait dengan tema melalui kajian teoritik. Kemudian peneliti menyusun dan mengembangkan skala atau alat ukur yang digunakan berdasarkan aspek dalam variabel yang diaman dalam variabe penyesuaian diri terdapat 28 item yang mewakili 4 aspek yang telah ditentukan, dan 60 item pada variabel kepuasan pernikahan yang mewakili 10 aspek yang telah ditentukan.

Tahap pelaksanaan dilakukan dengan menggunakan teknik tryout terpakai hal ini dikarenakan sulitnya mendapatkan subjek yang sesuai dengan kriteria yang diinginkan. Pada tahap pelaksanaan ini, peneliti menyebarkan 2 skala yaitu skala penyesuaian diri yang berjumlah 28 item yang dimana dari hasi uji validitas dengan standar 0,25, maka terdapat 9 item yang gugur dan indeks validitasnya berkisar antara $0,268-0,592$. Hasil pengujian reliabilitas pada Cronbach's Alpha dari penyesuaian diri adalah 0,831 . Hal ini berarti bahwa derajat ketelitian atau akurasi skala tersebut adalah 0,831. Apabila nilai reliabilitas mendekati 1 maka reliabilitas pada item semakin baik. Oleh karena itu reliabilitas pada skala penyesuaian diri adalah tinggi. Kemudian pada skala kepuasan pernikahan yang berjumlah 60 item yang dimana dari hasi uji validitas dengan standar 0,25, maka terdapat 6 item yang gugur dan indeks validitasnya berkisar antara 0,272 - 0,682. Hasil pengujian reliabilitas pada Cronbach's Alpha dari skala kematangan emosi adalah 0,948. Hal ini berarti bahwa derajat ketelitian atau akurasi skala tersebut adalah 0,948. Apabila nilai reliabilitas mendekati 1 maka reliabilitas pada item semakin baik. Oleh karena itu reliabilitas pada skala kepuasan pernikahan adalah tinggi.

Tahap Analisa data, pada tahap ini peneliti memulai dengan entry data untuk dilakukannya Analisa. Penelitian ini menggunakan SPSS (Statistical Program for Social Science) 21 dengan uji regresi linier sederhana dalam menganalisa data. Teknik ini digunakan untuk mengukur besarnya pengaruh variabel bebas $(X)$ terhadap variabel terikat $(\mathrm{Y})$ serta memprediksi variabel tergantung dengan menggunakan variabel bebas (Sarwono, 2015).

\section{HASIL}

Dari hasil uji kenormalan menggunakan One-Sample KolmogorovSmirnov Test, enggunakan dasar > 0,05 maka didapatkan hasil yaitu pada penyesuaian diri subjek memiliki nilai signifikan sebesar 0,410 dan pada kepuasan pernikahan memiliki nilai sigifikan sebesar 0,940. Dari hasil tersebut, dapat disimpulkan bahwa skala yang tersebar berdistribusi normal. 
Kemudian pada uji linieritas didapatkan hasil bahwa nilai signifikan dari penyesuaian diri dan kepuasan pernikahan sebesar 0,435>0,05 sehingga dapat disimpulkan bahwa skala tersebut linier atau searah. Kemudian dari hasil uji korelasi maka didapatkan hasil nilai koefisien korelasi atau $r=0,518$ sedangkan nilai koefisien determinasi atau $r^{2}=0,268$ sehingga penyesuaian diri terhadap kepuasan pernikahan pada pasangan yang menikah melalui proses ta'aruf memberikan pengaruh positif dengan nilai signifikan sebesar $26,8 \%$ dan sisanya sebesar $73,2 \%$ dipengaruhi oleh faktor lain.

Tabel 2. Hasil Analisa Data

\begin{tabular}{lc}
\hline \multicolumn{1}{c}{ Koefisien Korelasi } & Indeks Analisis \\
\hline Koefisien Korelasi $(\mathrm{r})$ & 0,518 \\
Koefisien Determinasi $\left(\mathrm{r}^{2}\right)$ & 0,268 \\
Standar Kesalahan & $1 \%(0,01)$ \\
Nilai Signifikan $(\mathrm{P})$ & 0,000 \\
\hline
\end{tabular}

Dari hasil yang diperoleh ialah adanya pengaruh yang siginfikan variabel $\mathrm{X}$ atau penyesuaian diri terhadap variabel $Y$ atau kepuasan pernikahan sebesar $26,8 \%$.

Tabel 3. Kategori Penyesuaian Diri

\begin{tabular}{lccc}
\hline Kategori & Rentang Skor & Frekuensi & Persentase \\
\hline Tinggi & $61-72$ & 36 & $30,5 \%$ \\
Sedang & $51-60,5$ & 64 & $54,2 \%$ \\
Rendah & $40-50,5$ & 18 & $15,3 \%$ \\
\hline
\end{tabular}

Dari tabel diatas, didapatkan hasil yaitu dari 118 subjek terdata 36 subjek memiliki kemampuan penyesuaian diri yang tinggi atau sebesar 30,5\%, kemudian 18 subjek memiliki kemampuan penyesuaian diri yang rendah atau sebesar 15,3\%, dan sisanya berjumlah 64 subjek memiliki penyesuaian iri yang sedang atau sebesar $54,2 \%$. Kemudian untuk mengetahui frekuensi kepuasan pernikahan dipengaruhi oleh penyesuaian diri, maka peneliti melakukan analisa yang dijabarkan dalam tabel dibawah yaitu:

Tabel 4. Kategori kepuasan pernikahan

\begin{tabular}{lccc}
\hline Kategori & Rentang Skor & Frekuensi & Persentase \\
\hline Tinggi & $182-208$ & 44 & $37,3 \%$ \\
Sedang & $156-181,5$ & 58 & $49,2 \%$ \\
Rendah & $130-155,5$ & 16 & $13,6 \%$ \\
\hline
\end{tabular}

Dari data tabel diatas, dari 118 subjek, terdapat 44 subjek yang memiliki tingkat kepuasan yang tinggi atau sebesar 37,3\%, kemudian 16 subjek memiliki tingkat kepuasan yang rendah atau sebesar $13,6 \%$, dan sisanya sebanyak 58 subjek atau sebesar $49,2 \%$ memiliki tingkat kepuasan yang sedang. 


\section{DISKUSI}

Penyesuaian diri merupakan proses adaptasi pada sebuah lingkungan, serta bagaimana individu menampilkan perannya pada lingkungan tersebut. Menurut Schneiders (Indrawati \& Fauziah, 2012) menyebutkan bahwa ciri-ciri dari penyesuaian diri yang baik adalah adanya pengetahuan tentang kekurangan serta kelebihan dalam dirinya, memiliki objektivitas diri dan penerimaan diri, mempunyai kontrol dan perkembangan diri, memiliki integritas pribadi yang baik, mempunyai tujuan dan arah yang jelas dari perbuatannya, memiliki cara pandang terhadap sesuatu, skala penilaian, mempunyai rasa humor yang sesuai, mempunyai rasa tanggungjawab yang tinggi, menunjukkan kematangan respon, adanya perkembangan kebiasaan yang baik, memiliki kemampuan beradaptasi, bebas dari respon-respon yang simptomatis atau cacat, memiliki kemampuan bekerjasama dan memiliki rasa kepekaan pada orang lain, memiliki minat yang besar dalam bekerja, adanya kepuasan dalam bekerja, memiliki orientasi yang kuat terhadap realita yang ada.

Kemudian Kartono (Utami, 2015) mengatakan bahwa individu yang berhasil dalam proses penyesuaian dirinya, ditandai dengan dapat memenuhi segala jenis kebutuhannya tanpa melebihkan atau mengurangi kepentingan kebutuhan yang lain, kemudian tidak mengganggu dan menghalangi individu lain dalam melakukan proses penyesuaian diri, kemudian melakukan atau melaksanakan pertanggungjawaban dalam terhadap masyarakat tempat ia tinggal.

Jika melihat dari hasil analisa yang dilakukan, maka bisa ditarik beberapa faktor yang mengakibatkan pengaruh penyesuaian diri relative kecil dikarenakan faktor usia subjek yang menikah dalam usia yang relative lebih muda, sebagaimana penelitian yang dilakukan oleh Utami (2015) yang berjudul penyesuaian diri remaja putri yang menikah muda yang dimana hasil yang didapatkan ialah beberapa subjek yang diteliti merasakan kebimbangan dalam menjalankan perannya sebagai seorang istri kemudian beberapa subjek juga merasakan ketidakbebasan setelah menikah hal inilah yang membuat mereka sulit untuk merasakan kepuasan dalam pernikahannya. Hal ini didukung oleh pendapat yang dipaparkan oleh Hurlock (2003) bahwa masa remaja merupakan masa yang sangat menentukan dalam fase perkembangan manusia karena pada masa ini, remaja akan banyak mengalami berbagai perubahan baik perubahan fisik maupun psikisnya. Perubahan-perubahan yang didapatkan oleh remaja akan membuat remaja tersebut mengalami kebingungan sehingga seringkali remaja tersebut menarik diri dari lingkungan di sekitarnya.

Kemudian faktor penghambat lainnya adalah kriteria yang ditentukan peneliti adalah umur pernikahan yang berada pada interval 1-5 tahun yang dimana pada interval tersebut merupakan masa-masa rawan dari sebuah pernikahan fase disaat pasangan baru ingin memulai perkenalan secara lebih mendalam, timbulnya konflikkonflik baru dalam kehidupan baru yang pasangan tersebut jalani, fase penerimaan keadaan baru bagai individu yang menikah, serta masa kebingungan dalam menjalankan peran baru dalam pernikahannya. Hal ini didukung oleh penelitian yang dilakukan oleh Anjani, C \& Suryanto (2006) yang memaparkan bahwa salah satu faktor penghambat lainnya yang dapat mempersulit proses penyesuaian diri dalam pernikahan adalah dikarenakan mayoritas subjek tidak mampu menerima perubahan sifat dan kebiasaan di awal pernikahan, suami maupun istri tidak memiliki inisiatif 
dalam menyelesaikan masalah, perbedaan budaya masing-masing diantara suami atau istri, tidak paham dengan peran dan tugas masing-masing dalam rumah tangga. Hal tersebut tdapat terlihat dari bagaimana cara suami atau istri menyikapi perubahan yang terjadi, perbedaan yang ada, serta bagaimana pola penyesuaian yang dimainkan terkait munculnya hal-hal yang baru dalam pernikahan yang mereka jalani, yang kesemuanya itu dirasa sangat kurang dalam membawa kebahagiaan hidup berumah tangga, yang hasilnya adalah masing-masing pasangan merasa gagal dalam melakukan penyesuaian diri satu sama lain.

Selanjutnya penelitian yang dilakukan oleh Srisusanti, S \& Zulkaida (2013) menyatakan bahwa faktor-faktor yang mempengaruhi kepuasan perkawinan pada istri adalah faktor hubungan interpersonal dengan pasangan, hal ini berdasarkan bahwa hubungan interpersonal merupakan pondasi paling utama ketika seseorang menjali sebuah hubungan baru dengan orang lain. kemudian faktor selanjutnya adalah faktor partisipasi keagamaan yang dimana hal ini sesuai dengan pendapat Stineet dkk. Srisusanti, S \& Zulkaida (2013) bahwa partisipasi keagamaan mempengaruhi tingkat kepuasan pernikahan. Dan faktor selanjutnya adalah kehidupan seksual. Ketiga faktor tersebut merupakan faktor-faktor yang dominan yang mempengaruhi kepuasan pernikahan.

\section{SIMPULAN DAN IMPLIKASI}

Melihat dari hasil penelitian yang telah dilakukan, dapat disimpulkan bahwa penyesuaian diri terhadap kepuasan pernikahan pada individu yang menikah melaui proses ta'aruf memiliki pengaruh yang kecil karena disebabkan berbagai faktor semisal faktor kurangnya pengetahuan terkain pernikahan, ketidaktahuan peran dalam pernikahan.

Implikasi dari penelitian ini adalah untuk pasangan yang akan menikah dan yang telah menikah melalui proses ta'aruf, dianjurkan belajar untuk meningkatkan penyesuaian diri dengan cara mempelajari keadaan lingkungan baru, karakter pasangan, serta menyiapkan diri untuk bias menerima keadaan dalam pernikahan seperti kekurangan pasangan, keadaan keluarga pasangan, serta tanggung jawab dan tugas yang akan dijalankan masing-masing.

\section{REFERENSI}

Afillah, S. dkk. (2013). Menikah memuliakan sunnah. Yogyakarta: Pro-U Media.

Al-Jauziyah, I. Q. (2016). Taman Orang-orang jatuh cinta dan memendam rindu. JatiwaringinPondok Gede, Bekasi: Darul Falah.

Anjani, C \& Suryanto. (2006). Pola penyesuaian pernikahan pada periode awal, 8(3), 198-210.

Ardhianita, I \& Andayani, B. (2005). Kepuasan pernikahan ditinjau dari berpacaran dan tidak berpacaran, 32(2), 101-111.

Armaya, S. (2017). Penyesuaian diri pasangan suami istri yang menikah melalui proses ta' aruf dikalangan kader pks di kota binjai. Universitas Islam Negeri Sumatera Utara Medan.

Ayuningtyas, S. R. (2015). Hubungan dukungan sosial keluarga dengan kepuasan pernikahan pada pasangan yang menikah di usia muda. Universitas Kristen Satya Wacana. 
Bradbury, T. N., Fincham, F. D., \& Beach, S. R. H. (2000). Research on the nature and determination of marital satisfaction: a decade in review. Journal of Marriage and the Family, 62(November), 964-980.

Dayakisnih, T \& Hudaniah. (2009). Psikologi sosial. Malang: UMM Press.

Dewi, L. H. (2009). Hubungan antara penyesuaian diri dalam perkawinan dengan kepuasan dalam perkawinan pada wanita yang bekerja. Universitas Sanata Dharma Yogyakarta.

Duvall, E, M \& Miller, B, C. (1985). Marriage and family development (edisi 6). The United States Of America: J.B. Lippincott.

Elhakim, L. (2015). Fenomena pacaran dunia remaja. Pekanbaru: Zanafa Publishing.

Hurlock, E. B. (2003). Psikologi perkembangan suatu pendekatan sepanjang rentang kehidupan (edisi 5). Jakarta: Erlangga.

Indrawati, E. S., \& Fauziah, N. (2012). Attachment dan penyesuaian diri dalam perkawinan. Jurnal Psikologi Undip, 11(1), 40-49.

Karim, A. Z., \& Desiningrum, D. R. (2015). Eksplorasi pengalaman penemuan makna cinta dengan interpretative phenomenological analysis. Jurnal Empati, 4(1), 43-48.

Listian, S. \& A. (2016). Subjective Well- being pada pasangan yang menikah. Jurnal RAP UNP, 7(1), 78-89.

Ramadhani, S. (2014). Perbedaan kepuasan pernikahan ditinjau dari jenis kelamin. Universitas Muhammadiyah Malang.

Salamudin, M. (2014). Hubungan antara dukungan sosial dengan penyesuaian diri pada wanita cerai (cerai hidup). Universitas Muhammadiyah Malang.

Sarwono, J. (2015). Rumus-rumus populer dalam SPSS 22 untuk riset skripsi. Yogyakarta: Andi Offset.

Srisusanti, S \& Zulkaida, A. (2013). Studi deskriptif mengenai faktor-faktor yang mempengaruhi kepuasan perkawinan pada istri. UG Jurnal, 7(06), 8-12.

Sugiyono. (2011). Metode penelitian kuantitatif dan kualitatif dan R and D. Bandung: Alfabeta.

Sundayani, Y, Koswara, H \& Qadriansyah. (2017). Self adjustment of single parent mother in south sulawesi - indonesia. Indonesian Journal of Social Work, 1(August), 76-94.

Takariawan, C. (2016). Dijalan dakwah aku menikah. Solo: Era Adicitra Intermedia.

Utami, F. T. (2015). Penyesuaian diri remaja putri yang menikah muda. PSIKIS-Jurnal Psikologi Islami, 1(1), 11-21. 